\title{
Effect of laser therapy combined with biomaterials for treatment of periodontal bone defects
}

\author{
Soares DM¹, Barros AAA ${ }^{1}$, Assis $\mathrm{AO}^{1}$, Lyra $\mathrm{S}^{1}$, Figueira $\mathrm{E}^{2}$, Dantas $\mathrm{EM}^{3}$, Gurgel BCV${ }^{4}$
}

\begin{abstract}
Objective: Evidence has shown that laser therapy can have a positive effect on the regeneration of periodontal tissues and improve the postoperative period through its antiinflammatory properties. The aim of the present review was to assess the effects of low-level and high-level laser in combination with different biomaterials on the regeneration of periodontal tissues in infrabony defects and furcation lesions. Materials and Methods: An electronic search of the PubMed database was performed, using ten specific descriptors. The search strategy gave 232 papers, 45 of which were initially selected based on the title, and following the reading of the abstracts, six of them were selected. After a complete reading of the texts, two papers were excluded for not fulfilling the inclusion criteria. Results: Thus, four papers were included in the present review, two of which employed low-level laser and two employed high-level laser in combination with enamel matrix derivative and bioactive glass. Non-significant results were found in the comparison of irradiated and non-irradiated groups using high-level laser, whereas statistically significant differences favoring the irradiated group were found with the use of low-level laser. Conclusions: Based on the data analyzed, low-level laser therapy has a positive effect on the regeneration of periodontal tissues, while high-level laser seems not to enhance the effect of enamel matrix derivative in the regeneration process.
\end{abstract}

Rev. Clin. Periodoncia Implantol. Rehabil. Oral Vol. 7(1); 25-28, 2014.

Key words: Laser therapy, bone regeneration, periodontal disease, biomaterials.

\section{INTRODUCTION}

Periodontitis is an infectious immuno-inflammatory disease that affects the dental support tissues, causing an exacerbated inflammatory process that results in alveolar bone loss as well as cementum and periodontal ligament ${ }^{(1)}$. Several surgical and non-surgical methods have been used in an attempt to rebuild tissues that have been destroyed by the progression of the disease ${ }^{(2-4)}$. These methods have been employed in combination with different biomaterials, such as enamel matrix derivative, bioactive glass, autogenous bone and different membranes, with the aim of enhancing the regeneration process ${ }^{(4,5)}$.

Laser therapy has been administered in the treatment of wounds and regeneration of biologic tissues in the last 30 years, especially in different fields of regenerative medicine and dentistry ${ }^{(6)}$. The literature reports beneficial effects from the use of laser for wound healing, bone regeneration and for the treatment of mucositis, xerostomia, pain and inflammation $^{(7)}$. The effect of laser therapy depends on parameters such as the wavelength, power density, dose, light spectrum, form of emission (continuous or pulsed) and pulse duration ${ }^{(8)}$. Moreover, high-level and low-level lasers have different functions. Due to its thermal effect, highlevel laser is employed more in surgical cutting activities. In contrast, lowlevel laser exerts a bio-stimulatory effect on the cellular level, enhancing the functional vitality of the mitochondria and accelerating the tissue repair process $^{(9)}$.

In periodontics, laser has been administered for different purposes $^{(1,5)}$ such as adjunct therapy in conventional mechanical root scaling and planing ${ }^{(10)}$ and to enhance both antimicrobial treatment ${ }^{(11)}$ and tissue regeneration process ${ }^{(7,12)}$. Some clinical and pre-clinical studies report improvements in bone regeneration potential with laser therapy in medicine and dentistry ${ }^{(13-15)}$. Thus, laser therapy could prove to be important to the regeneration of periodontal tissues as well.

The aim of the present study was to perform a review of the literature about the effect of low-level and high-level lasers in combination with biomaterials on the regeneration of periodontal tissues in cases of intrabony defects and furcation lesions.

\section{METHODOLOGY}

\section{Database}

An electronic search of the PubMed database was performed between December 15 and 23, 2011 for medical and dental periodicals and journals.

\section{Inclusion Criteria}

Type of study: prospective clinical trials.

Type of patient: infra-bone defect and/or furcation lesion.

Type of intervention: treatment of periodontal intrabony defects and/or furcation lesions using low-level or high-level laser in combination with biomaterials and/or bone graft.

Type of outcome: regeneration of periodontal tissues.

\section{Search Strategy}

The search of the database was limited to studies published between 2001 and 2011, in English, Portuguese, Spanish, German or French. The following terms were employed in the search:

- Laser therapy AND periodontal regeneration.

- Low laser therapy AND periodontal regeneration.

- Laser therapy AND periodontal regeneration AND bone regeneration.

- Low laser therapy AND periodontal regeneration AND bone regeneration.

- Laser therapy AND infrabony defects OR furcation lesion.

- Laser treatment AND periodontal defects.

- Laser treatment AND furcation treatment.

- Laser therapy AND periodontal defects AND bone graft.

- Laser therapy AND periodontal regeneration AND biomaterial.

- Low laser therapy AND periodontal regeneration AND biomaterial.

1. Dentista. Master en Odontología. Departamento de Odontología de la Universidad Federal del Río Grande del Norte-UFRN. Natal-RN, Brasil.

2. Dentista, PhD. Departamento de Odontología de la Universidad Federal del Río Grande del Norte-UFRN. Natal-RN, Brasil.

3. Dentista, PhD. Profesor Adjunto II de Clínica Integrada-Periodoncia. Departamento de Odontología de la Universidad Federal del Río Grande del Norte-UFRN. Natal-RN, Brasil.

4. Dentista, PhD. Profesor Adjunto III de Clínica Integrada-Periodoncia. Departamento de Odontología de la Universidad Federal del Río Grande del Norte-UFRN. Natal-RN, Brasil. 


\section{Selection of Studies}

The selection of studies was performed by two reviewers as follows:

1) Assessment of titles of studies identified through the application of the search strategy.

2) Pre-selection of papers with titles that appeared to correspond to the aims of the present review for the analysis of their abstracts.

3) Reading of the full texts that appeared to fulfill the inclusion criteria, including studies with abstracts that did not provide sufficient information for a clear decision.

4) Final selection of studies that fulfilled the inclusion criteria

\section{RESULTS}

\section{Search Results}

The search strategy yielded a total of 232 studies, 45 of which were initially selected based on the title. Following the reading the abstracts, 6 articles were selected and they had their full texts read; two studies were excluded for not meeting the inclusion criteria. Thus, four studies were included in the present review. The flowchart (Figure 1) details the study selection and Chart 1 lists the two studies excluded and the reasons for exclusion.

A manual search was also carried out of the references listed in the selected studies as well as the following periodicals: Journal of Periodontology, Laser in Surgery and Medicine, Laser in Medical Science, Photomedicine and Laser Surgery and Journal of Clinical Periodontology. However, no other studies met the inclusion criteria.

\section{Description of Studies and Methodological Quality}

Among the four studies selected, two assessed the influence of laser on periodontal regeneration based on its effectiveness in the debridement of granulation tissue ${ }^{(10)}$ and root conditioning ${ }^{(16)}$ in combination with biomaterials. The other two studies assessed the influence of laser therapy on periodontal tissues with regard to enhancing the effect of biomaterials used in tissue regeneration ${ }^{(7,12)}$. Table 1 summarizes the methods employed in the selected studies. Regarding tissue regeneration in furcation lesions, only one study was found using the search strategy ${ }^{(11)}$, but it was not included in the present review for not meeting the inclusion criteria (Chart 1).

The eligibility criteria in the four studies were similar: Diagnosis of chronic periodontal disease, two or more intrabony defects with a probing depth $\geq 6 \mathrm{~mm}$ and periodontal bone defects $\geq 3 \mathrm{~mm}$.

The studies evaluated their patients using clinical parameters alone, except for the study by Ozceliket al. ${ }^{(7)}$, which involved both clinical and radiographic evaluations. All studies had a test group and a control group, with randomization regarding the allocation of the patients to different groups. Three of the four studies performed two types of treatment on each individual ${ }^{(7,12,16)}$.

The sample size calculation was not reported in any of the studies. However, the examiners were calibrated and the procedure was described in all four studies. Three studies used enamel matrix derivative (Emdogain $\left.{ }^{\circledR}\right)$ as biomaterial ${ }^{(7,10,12)}$ and another used bioactive glass as graft material ${ }^{(12)}$.

\section{Main Results of the Studies}

Studies using the high-level laser ${ }^{(10,16)}$ did not show any influence on periodontal regeneration. The use of low-level laser therapy showed to be effective on periodontal bone regeneration when combined with bioative glass ${ }^{(12)}$ and enamel matrix derivative ${ }^{(7)}$. Additional information is described in Table 1.

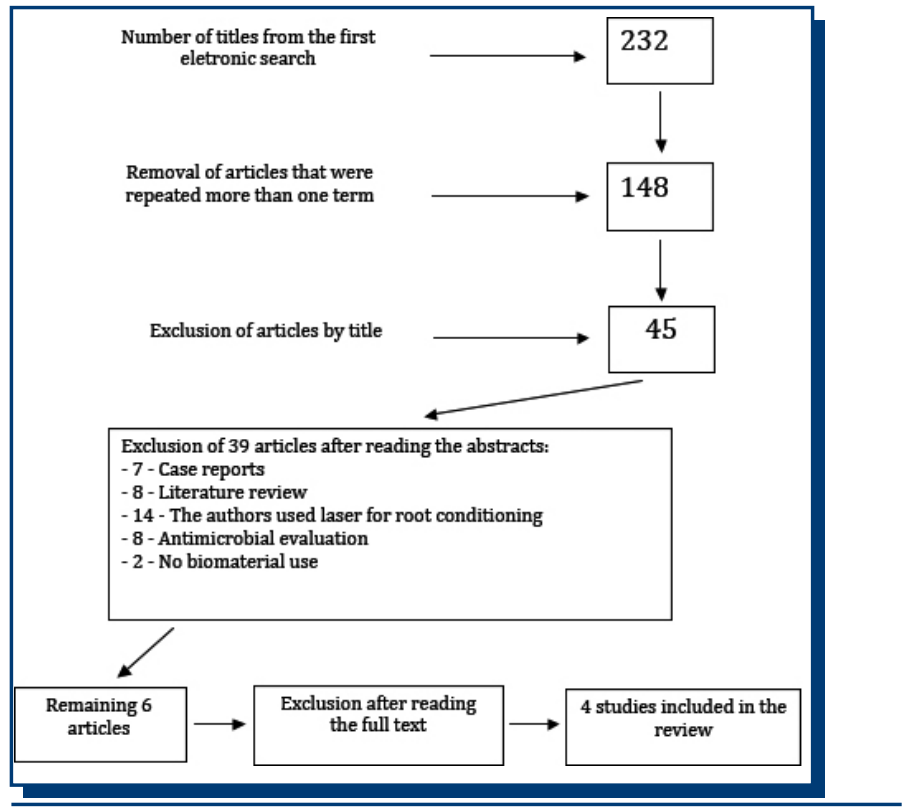

Figure 1. Flowchart illustrating the process of inclusion and exclusion.

Table 1. Summary of methods employed in studies selected.

\begin{tabular}{|c|c|c|c|c|}
\hline & Dilsiz et al. [16] & AboElsaad et al. [12] & Ozcelik et al. [7] & Schwarz et al. [10] \\
\hline Study design & $\begin{array}{l}\text { Randomized, controlled, } \\
\text { double-blindclinical trial with } \\
\text { split-mouth design }\end{array}$ & $\begin{array}{l}\text { Randomized clinical trial with } \\
\text { split-mouth design }\end{array}$ & $\begin{array}{l}\text { Randomized, placebo- } \\
\text { controlled, double-blind, clinical } \\
\text { trial with split-mouth design }\end{array}$ & Randomized clinical trial \\
\hline $\mathrm{N}^{\circ}$ of patients & 21 patients & 20 patients & 22 patients & 22 patients \\
\hline Patient age & $33-46$ years (mean: 39.2 years) & $33-57$ years (mean: 45 years) & $31-49$ years & $32-61$ years \\
\hline Diagnosis & $\begin{array}{l}\text { Chronic periodontal disease } \\
\text { with infrabony defects without } \\
\text { furcation involvement }\end{array}$ & $\begin{array}{c}\text { Moderate to advanced } \\
\text { periodontal disease with loss } \\
\text { of periodontal support tissue } \\
\text { and bilateral infrabony defects } \\
\text { involving } 1,2 \text { or } 3 \text { walls }\end{array}$ & $\begin{array}{l}\text { Chronic periodontal disease } \\
\text { with } 2 \text { contralateral infrabony } \\
\text { defects in the same time of } \\
\text { tooth with } P D \geq 6 \mathrm{~mm}\end{array}$ & $\begin{array}{c}\text { Chronic periodontal disease } \\
\text { with infrabony defect with PD } \\
\geq 6 \mathrm{~mm}\end{array}$ \\
\hline Number of bone defects & 42 defects & 40 defects & 44 defects & 22 defects \\
\hline Biomaterial employed & EMD & Bioactive glass & EMD & EMD \\
\hline Treatment & $\begin{array}{c}\text { Test group: EMD + conditioning } \\
\text { with laser; Control group: EMD } \\
\text { + EDTA } 24 \%\end{array}$ & $\begin{array}{l}\text { Test group: graft with bioactive } \\
\text { glass + laser; Control group: } \\
\text { graft with bioactive glass }\end{array}$ & $\begin{array}{l}\text { Test group: EMD + laser; } \\
\text { Control group: EMD }\end{array}$ & $\begin{array}{c}\text { Test group: EMD + removal } \\
\text { of granulation tissue with } \\
\text { laser; Control group: Hand } \\
\text { instruments + EDTA and EMD }\end{array}$ \\
\hline Type of laser & High-level laser (Nd:YAG) & Low-level laser (GaAlAs) & Low-level laser (diode) & High-level laser (ER:YAG) \\
\hline Laser parameters & $\begin{array}{l}\text { WL: } 1064 \mathrm{~nm} \\
\text { ED: } 141.54 \mathrm{~J} / \mathrm{cm}^{2} \\
\text { Frequency: } 10 \mathrm{~Hz} \\
\text { Pulsed }\end{array}$ & $\begin{array}{c}\text { WL: } 830 \mathrm{~nm} \\
\text { ED: } 16 \mathrm{~J} / \mathrm{cm}^{2} \\
\text { Power: } 40 \mathrm{~mW} \\
\text { Continual waves }\end{array}$ & $\begin{array}{l}\text { WL: } 588 \mathrm{~nm} \\
\text { ED per 5-min of irradiation: } 4 \mathrm{~J} / \mathrm{cm}^{2} \\
\text { Continual waves }\end{array}$ & $\begin{array}{c}\text { WL: } 2940 \mathrm{~nm}^{*} \\
\text { Pulsed infrared radiation } 160 \\
\mathrm{~mJ} / \text { pulse; } 10 \text { pulses/s; ED at tip } \\
\text { approximately } 120 \mathrm{~mJ} / \text { pulse }\end{array}$ \\
\hline Exposure time & $\begin{array}{c}120 \text { s (60s in vestibular and } \\
60 \text { s in lingual region, with } \\
20-\text { second interval between } \\
\text { applications) }\end{array}$ & 60 s per application & $\begin{array}{l}10 \text { min per application ( } 5 \text { min in } \\
\text { vestibular and } 5 \text { min in lingual } \\
\text { region) }\end{array}$ & Not reported \\
\hline
\end{tabular}




\begin{tabular}{|c|c|c|c|c|}
\hline & Dilsiz et al. [16] & AboElsaad et al. [12] & Ozcelik et al. [7] & Schwarz et al. [10] \\
\hline Laser application times & At the time of surgery & $\begin{array}{l}\text { At the time of surgery, } 3,5 \text { and } \\
7 \text { days postoperatively }\end{array}$ & $\begin{array}{l}\text { During surgery, after suturing } \\
\text { and for another } 5 \text { consecutive } \\
\text { days }\end{array}$ & At the time of surgery \\
\hline Clinical evaluation times & $\begin{array}{l}\text { Prior to surgery, } 6 \text { and } 12 \\
\text { months after surgery }\end{array}$ & $\begin{array}{l}\text { At the time of surgery, } 3 \text { and } \\
6 \text {-months after surgery }\end{array}$ & $\begin{array}{l}\text { Prior to surgery } 2,6 \text { and } \\
12 \text {-months after surgery }\end{array}$ & $\begin{array}{c}\text { Prior to surgery and 6-months } \\
\text { after surgery }\end{array}$ \\
\hline $\begin{array}{l}\text { Radiographic evaluation } \\
\text { times }\end{array}$ & None & $\begin{array}{l}\text { Prior to surgery, } 3 \text { and 6-months } \\
\text { after surgery }\end{array}$ & None & None \\
\hline Results & $\begin{array}{l}\text { Comparing test and control } \\
\text { groups, significant clinical } \\
\text { improvements for PD, GR and } \\
\text { CAL; Lower means in control } \\
\text { group }\end{array}$ & $\begin{array}{c}\text { At 3-month evaluation, } \\
\text { irradiated group had } \\
\text { significantly lower PD values } \\
\text { compared to control group; at } 6 \\
\text { months, means in both groups } \\
\text { were similar; radiographically, } \\
\text { significantly greater amount of } \\
\text { bone tissue formed in test group } \\
\text { at } 3 \text { and } 6 \text {-month evaluations }\end{array}$ & $\begin{array}{l}\text { Comparing laser and control } \\
\text { groups, significant means } \\
\text { for GR in laser group at all } \\
\text { postoperative evaluation times } \\
(2,6 \text { and } 12 \text {-months })\end{array}$ & $\begin{array}{l}\text { No significant differences } \\
\text { between treatment modalities } \\
\text { (with and without laser) for } \\
\text { any clinical parameter at any } \\
\text { evaluation time }\end{array}$ \\
\hline Conclusions & $\begin{array}{l}\text { Both treatments resulted } \\
\text { in improvements in clinical } \\
\text { parameters, but the Nd:YAG } \\
\text { laser used for root conditioning } \\
\text { appears not to have enhanced } \\
\text { the effect of EMD compared } \\
\text { to EDTA }\end{array}$ & $\begin{array}{l}\text { A positive effect was found } \\
\text { with laser on acceleration of } \\
\text { formation and mineralization of } \\
\text { new bone tissue }\end{array}$ & $\begin{array}{l}\text { LLLI significantly enhanced } \\
\text { effects of EMD, reducing GR } \\
\text { and postoperative pain and } \\
\text { swelling }\end{array}$ & $\begin{array}{l}\text { Laser treatment does not } \\
\text { appear to have improved } \\
\text { clinical results in comparison to } \\
\text { treatment employed in control } \\
\text { group }\end{array}$ \\
\hline
\end{tabular}

PD: Probing depth.

EMD: Enamel matrix derivative (Emdogain $®)$.

WL: Wavelength.

ED: Energy density.

* Datum referring to wavelength furnished in $\mu \mathrm{m}$ and converted to $\mathrm{nm}$, multiplying by 1000 . PI: Plaque index.

Chart 1. Papers excluded following analysis of full text.

\begin{tabular}{|c|c|c|c|}
\hline Study & Periodical & Title & $\begin{array}{l}\text { Reason for } \\
\text { exclusion }\end{array}$ \\
\hline $\begin{array}{l}\text { Andrade et } \\
\quad \text { al. } 11\end{array}$ & $\begin{array}{l}\text { Laser in Medical } \\
\text { Science }\end{array}$ & $\begin{array}{c}\text { Nd:YAG } \\
\text { laser clinical } \\
\text { assisted in } \\
\text { class II furcation } \\
\text { treatment }\end{array}$ & $\begin{array}{l}\text { Investigated effect } \\
\text { of laser on reduction } \\
\text { of microorganisms } \\
\text { in furcation lesions } \\
\text { with and without root } \\
\text { scaling }\end{array}$ \\
\hline $\begin{array}{l}\text { Sculean et } \\
\text { al.5 }\end{array}$ & $\begin{array}{c}\text { Journal } \\
\text { of Clinical } \\
\text { Periodontology }\end{array}$ & $\begin{array}{c}\text { Healing of } \\
\text { infrabony } \\
\text { defects following } \\
\text { surgical } \\
\text { treatment with } \\
\text { or without an } \\
\text { Er:YAG laser. A } \\
\text { pilot study }\end{array}$ & $\begin{array}{c}\text { Assessed efficacy } \\
\text { of laser in removal } \\
\text { of granulation tissue } \\
\text { of infrabony defects } \\
\text { in comparison to } \\
\text { manual instruments } \\
\text { and ultrasound with } \\
\text { no regeneration } \\
\text { method }\end{array}$ \\
\hline
\end{tabular}

\section{DISCUSSION}

Both high and low-level lasers have been widely used in dentistry with regenerative effects ${ }^{(6)}$. Low-level laser therapy is absorbed by the tissues and stimulates biomodulation in the processes of cell proliferation and recruitment ${ }^{(17)}$. High-level lasers produce heat and promote tissue decontamination. The action of laser depends on its intensity and has heterogeneous characteristics related to different tissues and cell types from the optical standpoint ${ }^{(6)}$. The choice of laser type should be based on its interaction with the target tissue.

Among the selected studies for the present review, two evaluated low-level laser (GaAlAs and diode) and reported its effects on cell biostimulation as well as its antiinflammatory properties ${ }^{(7,12)}$. The other two studies analyzed high-level laser (Nd:YAG and ER:YAG), and focused on tissue debridement ${ }^{(16)}$ and root conditioning ${ }^{(10)}$. High-level laser also simultaneously decontaminates the irradiated surfaces, which
GI: Gingival index.

BP: Bleeding on probing.

GR: Gingival recession.

CAL: Clinical attachment loss.

** Diamaix, version 3.3.3. (2006).

LLLI: Low-level laser irradiation.

reduces the risk of infection of the surgical wound and enhance the tissue repair process ${ }^{(11)}$.

The literature reports that the wavelength used exerts a direct influence on light absorption by tissues, leading to different results in the same target tissue or cell type. Moore et al..$^{(8)}$ evaluated the effect of laser irradiation at different wavelengths $(625,635,645,655,665,675$ and $810 \mathrm{~nm}$ ) on the proliferation of two cell types (fibroblasts and endothelial cells) over a 72 hour cultivation time. The results demonstrated an increase in the growth of endothelial cells at all wavelengths studied and the fibroblasts responded positively to all wavelengths, except $810 \mathrm{~nm}$.

In the selected studies for the present review, the results obtained were similar despite the use of different wavelengths. The outcomes revealed that the use of low-level laser always demonstrated significantly better results in comparison to non-irradiated control group, even with different methodological aspects. However, the same did not occur with high-level laser irradiation.

Another point worth mentioning is the short clinical evaluation period of the studies, with a maximal follow up of 12 months, which was only carried out in two studies ${ }^{(10,16)}$. This finding may be explained by the recent publication of some studies included in the review as well as the difficulty in conducting longitudinal studies.

With regard to the use of laser therapy in periodontics, some studies have addressed the effects regarding decontamination ${ }^{(11,18)}$, basic periodontal therapy ${ }^{(19,20)}$ and non-surgical periodontal treatment ${ }^{(21)}$. However, the literature on laser employed for periodontal tissue regeneration is scarce, as only four clinical trials were found for the present review ${ }^{(7,10,12,16)}$. Thus, it is not possible to have better conclusions about the use of laser in improving periodontal regeneration.

Nissan et al. ${ }^{(22)}$ carried out a pre-clinical study using Wistar rats, in which bilateral defects were performedin the mandible. The right side received low-level laser irradiation in three different time intervals (1, 2 and 4 weeks) with two different intensities $\left(4\right.$ and $\left.22.4 \mathrm{~mW} / \mathrm{cm}^{2}\right)$, while the left side served as control. The results demonstrated that the group treated with the lower intensity $\left(4 \mathrm{~mW} / \mathrm{cm}^{2}\right)$ exhibited a significant increase in radiopacity and bone mineralization in the second and fourth weeks. These results are corroborated by those reported in the study by AboElsaad et al. ${ }^{(12)}$, who report an increase in radiopacity in a longer 
evaluation period ( 3 and 6 months), suggesting that low-level laser may intensify the mineralization process.

Sculean et al. ${ }^{(5)}$ carried out a study similar to that by Schwarz et al.(10), but without periodontal regeneration. The authors used the same type of laser and the same parameters, but biomaterials were not employed in any of the groups. No statistically significant differences were found between groups before surgery and six months after surgery. These data are in agreement with findings described by Schwarz et al. ${ }^{(10)}$ and Dilsiz et al. ${ }^{(16)}$, who employed similar experimental designs, but combined laser therapy with enamel matrix derivate (EMD).

However, it is still early to affirm the true effects of laser therapy on regenerated periodontal tissues, since few and heterogeneous studies have been addressed besides the lack of longitudinal results that prove the benefits of this therapy on periodontal regeneration. Additionally, wavelength, energy density, exposure time, laser parameters, type of laser, laser application times should also be addressed in future studies.

\section{CONCLUSION}

Within the limits of this review and based on the studies analyzed, low-level laser when associated to biomaterials seems to have positive effects on periodontal tissue regeneration and improves the postoperative period due to its antiinflammatory characteristics. In contrast, high-level laser used for root conditioning and the debridement of root surfaces in combination with the use of enamel matrix derivate may not have positive effect on the regeneration of periodontal tissues.

\section{CONFLICT OF INTEREST STATEMENT}

None declared.

\section{REFERENCES}

1. Aykol G, Baser U, Maden I, Kazak Z, Onan U, Tanrikulu-Kucuk S, Ademoglu $\mathrm{E}$, Issever $\mathrm{H}$, Yalcin $\mathrm{F}$. The effect of low-level laser therapy as an adjunct to nonsurgical periodontal treatment. J Periodontol, 2011; 82: 481-488.

2. Tonetti MS, Cortellini P, Lang NP, Suvan JE, Adriaens P, Dubravec D, Fonzar A et al. Clinical outcomes following treatment of human intrabony defects with GTR/bone replacement material or access flap alone. A multicenter randomized controlled clinical trial. J Clin Periodontol, 2004; 31: 770-776.

3. Harrel SK, Wilson TG, Nunn ME. Prospective assessment of the use of ename matrix proteins with minimally invasive surgery, J Periodontol, 2005; 76: 380-384

4. Cortellini $P$, Tonetti MS. A minimally invasive surgical technique with an ename matrix derivative in the regenerative treatment of intra-bony defects: A novel approach to limit morbidity. J Clin Periodontol, 2007; 34: 87-93.

5. Sculean A, Schwarz F, Berakdar M, Windisch P, Arweiler NB, Romanos GE. Healing of intrabony defects following surgical treatment with or without an Er:YAG laser. A pilot study. J Clin Periodontol, 2004; 31: 604-608. doi: 10.1111/j.1600051X.2004.00525x

6. Khalid M, AIGhamdi, Kumar A, Moussa NA. Low-level laser therapy: A useful technique for enhancing the proliferation of various cultured cells. Lasers Med Sci, 2012; 27: 237-249.

7. Ozcelik O, Haytac MC, Seydaoglu G. Enamel matrix derivative and low-level laser therapy in the treatment of intra-bony defects: A randomized placebocontrolled clinical trial. J Clin Periodontol, 2008; 35: 147-156. doi: 0.1111/j.1600051X.2007.01176.x.

8. Moore P, Ridgway TD, Higbee RG, Howard EW, Lucroy MD. Effect of wavelength on low-intensity laser irradiation stimulated cell proliferation in vitro. Lasers Surg Med, 2005; 36: 8-12.

9. Brugnera A Jr, Zanin F, Barbin EL, Spano JC, Santana R, Pécora JD. Atlas de laserterapia aplicada a clínica odontológica. $2^{\text {ed }}$. São Paulo: Editora Santos. 2003. 10. Schwarz F, Sculean A, Georg T, Becker J. Clinical evaluation of the Er:YAG laser in combination with an enamel matrix protein derivative for the treatment of intrabony periodontal defects: A pilot study. J Clin Periodontol, 2003; 30: 975-981. 11. Andrade AKP, Feist IS, Pannuti CM, Cai S, Zezell DM, De Micheli G. Nd:YAG laser clinical assisted in class II furcation treatment. Lasers Med Sci, 2008; 23: 341-347.

12. AboElsaad NS, Soory M, Gadalla LMA, Ragab LI, Dunne S, Zalata KR, Louca C. Effect of soft laser and bioactive glass on bone regeneration in the treatment of infra-bony defects (a clinical study). Lasers Med Sci, 2009; 24: 387-395.
13. Jakse N, Payer M, Tangl S, Berghold A, Kirmeier R, Lorenzoni M. Influence of low-level laser treatment on bone regeneration and osseointegration of dental implants following sinus augmentation: An experimental study on sheep. Clin Oral Impl Res, 2007; 18: 517-524.

14. Khadra M, Ronold HJ, Lyngstadaas SP, Ellingsen JE, Haanaes HR. Low-level laser therapy stimulates bone implant interaction: An experimental study in rabbits. Clin Oral Impl Res, 2004; 15: 325-332.

15. Kawasaki K, Shimizu N. Effects of low-energy laser irradiation on bone remodeling during experimental tooth movement in rats. Lasers Surg Med, 2000 26: 282-291

16. Dilsiz A, Canakci V, Aydin T. The combined use of Nd:YAG laser and ename matrix proteins in the treatment of periodontal infrabony defects. $J$ Periodontol, 2010; 81: 1411-1418.

17. Bouvet-Gerbettaz S, Merigo E, Rocca JP, Carle GF, Rochet N. Effects of lowlevel laser therapy on proliferation and differentiation of murine bone marrow cells into osteoblasts and osteoclasts. Lasers Surg Med, 2009; 41: 291-297.

18. Pinheiro SL, Donegá JM, Seabra LM, Adabo MD, Lopes T, do Carmo TH, Ribeiro $\mathrm{MC}$ et al. Capacity of photodynamic therapy for microbial reduction in periodontal pockets. Lasers Med Sci, 2010; 25: 87-91.

19. Lui J, Corbet EF, Jin L. Combined photodynamic and low-level laser therapies as an adjunct to nonsurgical treatment of chronic periodontitis. J Periodontal Res, 2011; 46: 89-96. doi: 10.1111/j.1600-0765.2010.01316.x.

20. Zegaib S, Lage-Marques JL, Vieira MM, Junior AR, Feres M, Shibli JA, Figueiredo LC. Phenomenon of laser power loss during curettage of infected periodontal pockets. Photomed Laser Surg, 2011; 29: 657-662.

21. Rotundo R, Nieri M, Cairo F, Franceschi D, Mervelt J, Bonaccini D, Esposito M et al. Lack of adjunctive benefit of Er:YAG laser in non-surgical periodontal treatment: A randomized split-mouth clinical trial. J Clin Periodontol, 2010; 37: 526-533. 22. Nissan J, Assif D, Gross MD, Yaffe A, Binderman I. Effect of low intensity lase irradiation on surgically created bony defects in rats. J Oral Rehabil, 2006; 33: 619-624. 